\title{
Causation of human urothelial cancer: there are challenging new data!
}

\author{
Hermann M. Bolt
}

Received: 10 August 2014 / Accepted: 13 August 2014 / Published online: 26 August 2014

(C) Springer-Verlag Berlin Heidelberg 2014

Very recently, the following aspects regarding causes of human urinary bladder cancer were addressed in this journal: (1) genome-wide association studies have identified a multitude of single nucleotide polymorphisms (SNPs) associated with moderate bladder cancer risks (Selinski 2014). It appears likely that such "wimp SNPs" collectively have a strong influence on cancer development, because of their high numbers (Golka et al. 2011). At this time, it can be predicted that many SNPs relevant for human bladder cancer are remaining undetected. (2) Rota et al. (2014) presented an updated meta-analysis of epidemiological studies on workers in aluminium production industries, iron/steel industries, asphalt workers and carbon black production, which in total confirmed increased risks of bladder cancer in occupations with exposures to polycyclic aromatic hydrocarbons (PAH). However, because for all industries reviewed the excess risks were modest, influences of possible bias or residual confounders could not be ruled out.

For occupational induction of urothelial cancer of the urinary bladder, aromatic amines are viewed as the most relevant cause (Golka et al. 2003; Kim et al. 2007). At the same time, the most important non-occupational causality of urinary bladder cancer is smoking (IARC 2004). Chemical exposures to carcinogens, both occupational and by smoking, are complex. Within this complexity, the role of carcinogenic aromatic amines is a matter of discussion, which is partly driven by practical matters of legal compensation of occupational diseases (Weiß et al. 2010; Henschler et al. 2012). Within technical PAH mixtures (DGUV

H. M. Bolt $(\square)$

Leibniz Research Centre for Working Environment and Human

Factors at the TU Dortmund (IfADo), Ardeystr. 67,

44139 Dortmund, Germany

e-mail: bolt@ifado.de
2011) and tobacco smoke (Weiß et al. 2010; Plöttner et al. 2012), the contents of carcinogenic aromatic amines are usually small. Therefore, the role of PAH as a specific reason for human urinary bladder cancer requires (re-) consideration.

In this context, relevant contributions have appeared in Archives of Toxicology in recent years. Verma et al. (2012) exposed primary porcine urothelial cells (PUBEC) in culture to benzo[a]pyrene and found a high intracellular accumulation, leading to concentrations ranging from 7.3 to $35.7 \mu \mathrm{M}$ within cells exposed to $0.5 \mu \mathrm{M}$ benzo[a]pyrene. Srivastava et al. (2008) demonstrated that the exon 3 His genotype of the microsomal epoxide hydrolase was more prone to the risk of sporadic bladder cancer in North India. Thus, from entirely different perspectives, experimental and epidemiological data point to some specific role of PAH in the induction of human urothelial cancer.

For the bioactivation of both PAH and aromatic amines, a key process is the local expression of CYP1A1. Dörrenhaus et al. (2007) found this expression increased in human exfoliated urothelial cells of cigarette smokers, compared to non-smokers. Plöttner et al. (2009), using the PUBEC model, observed a strong, concentration-dependent CYP1A1 induction in a "responsive" sub-population of urothelial cells with benzo[a]pyrene in a concentration of 1 to $10 \mu \mathrm{M}$. By contrast, no such induction was seen in a "non-responsive" subpopulation of cells , up to the highest tested concentration of $100 \mu \mathrm{M}$.

Having this in mind, Borza et al. (2008) studied the interaction between the aromatic amine 4-aminobiphenyl $(1-50 \mu \mathrm{M})$ and benzo[a]pyrene $(1 \mu \mathrm{M})$ in the PUBEC model. As expected, benzo[a]pyrene increased mRNA expression of CYP1A1, whereas 4-aminobiphenyl alone had no such effect. However, upon co-exposure with 4-aminobiphenyl (or alternatively 2-naphthylamine), the 
induction of CYP1A1 by benzo[a]pyrene was enhanced, which was confirmed by Western blot data. A similar combination effect was seen for COX-2 and UGT1. Together with the data of Verma et al. (2012) of a concentration of benzo[a]pyrene in urinary bladder cells, this points to a biologically significant multiplicative combination effect of carcinogenic polycyclic aromatic hydrocarbons and carcinogenic aromatic amines on the epithelium of the urinary bladder. From a mechanistic angle, this is in line with the recent epidemiological meta-analysis by Rota et al. (2014). Therefore, it appears not plausible that the increased risks found associated with specific occupations are only caused by bias or confounders.

Another highly relevant cause of human urothelial cancer, for which combination effects with other toxicants are of scientific concern, is arsenic (Golka et al. 2010; Bolt 2012, 2013). In a recent review, Bustaffa et al. (2014) have summarised the genetic and epigenetic mechanisms in arsenic carcinogenicity. Both mechanistic pathways are interacting and relevant for arsenic carcinogenesis. Specifically for the urinary bladder, a recent study by Wang et al. (2014) used human urothelial cells in vitro and showed that sustained low-dose arsenic exposure resulted in epigenetic changes via lipocalin-2 promoter hypomethylation and overexpression, which was seen connected with carcinogenicity. Thus, the essential implication of epigenetic mechanisms in arsenic carcinogenesis evolves as an important point for risk management, because it could allow the derivation of health-based limit values.

Taken together, there are challenging new data on both endogenous (genetic) and exogenous (toxicological) factors connected with the origin of human urothelial cancer. A central topic for future research will be interaction(s) of these factors. Inter-disciplinary research in this field is highly encouraged, as well as its timely publication in our journal!

\section{References}

Bolt HM (2012) Arsenic: an ancient toxicant of continuous public health impact, from Iceman Ötzi until now. Arch Toxicol 86(6):825-830

Bolt HM (2013) Current research trends on arsenic toxicology. Arch Toxicol 87(6):925-926

Borza A, Plöttner S, Wolf A, Behm C, Selinski S, Hengstler JG, Roos PH, Bolt HM, Kuhlmann J, Föllmann W (2008) Synergism of aromatic amines and benzo[a]pyrene in induction of Ah receptordependent genes. Arch Toxicol 82:973-980

Bustaffa E, Stoccoro A, Bianchi F, Migliore L (2014) Genotoxic and epigenetic mechanisms in arsenic carcinogenicity. Arch Toxicol 88:1043-1067
DGUV (2011) Aromatische amine. Eine Arbeitshilfe im Berufskrankheiten-Feststellungsverfahren. BK-Report 2/2011. Deutsche Gesetzliche Unfallversicherung, Berlin. ISBN: 978-3-88383-8847; ISBN online: 978-88383-885-4

Dörrenhaus A, Müller T, Roos PH (2007) Increased CYP1A1 expression in human exfoliated urothelial cells of cigarette smokers compared to non-smokers. Arch Toxicol 81:19-25

Golka K, Wiese A, Assenato G, Bolt HM (2003) Occupational exposure and urological cancer. World J Urol 21(6):382-391

Golka K, Hengstler JG, Marchan R, Bolt HM (2010) Severe arsenic poisoning: one of the largest man-made catastrophies. Arch Toxicol 84(8):583-584

Golka K, Selinski S, Lehmann M-L, Blaszkewicz M, Marchan R, Ickstadt K, Schwender H, Bolt HM, Hengstler J (2011) Genetic variants in urinary bladder cancer: collective power of the "wimp SNPs". Arch Toxicol 84:539-554

Henschler D, Norpoth K, Thielmann HW, Woitowitz H-J (2012) Blasenkrebs durch aromatische Amine als Berufskrankheit: zur Validität der neuen berufsgenossenschaftlichen Dosisgrenzwerte. Zbl Arbeitsmed 62:64-75

IARC [International Agency for Research on Cancer] (2004) Tobacco smoking and involuntary smoking. IARC Monogr Eval Carcinog Risks Hum 83:1-1438

Kim Y, Park J, Shin YC (2007) Dye-manufacturing workers and bladder cancer in South Korea. Arch Toxicol 81:381-384

Plöttner S, Selinski S, Bolt HM, Degen GH, Hengstler JG, Roos PH, Föllmann W (2009) Distinct subtypes of urinary bladder epithelial cells with inducible and non-inducible cytochrome P450 1A1. Arch Toxicol 83:131-138

Plöttner S, Behm C, Bolt HM, Föllmann W (2012) Effects of cigarette smoke condensate on primary urothelial cells in vitro. J Toxicol Environ Health A 75(19-20):1194-1205

Rota M, Bosetti C, Boccia S, Boffetta P, La Vecchia C (2014) Occupational exposures to polycyclic aromatic hydrocarbons and respiratory and urinary tract cancers: an updated systemic review and a meta-analysis to 2014. Arch Toxicol 88:1479-1490

Selinski S (2014) Urinary bladder cancer risk variants: recent findings and new challenges of GWAS and confirmatory studies. Arch Toxicol 88:1469-1475

Srivastava DS, Mandhani A, Mittal RD (2008) Genetic polymorphisms of cytochrome P450 CYP1A1 (*2A) and microsomal epoxide hydrolase gene, interactions with tobacco-users, and susceptibility to bladder cancer: a study from North India. Arch Toxicol 82(9):633-639

Verma N, Pink M, Petrat F, Rettenmeier AW, Schmitz-Spanke S (2012) Exposure of primary porcine urothelial cells to benzo(a) pyrene: in vitro uptake, intracellular concentration, and biological response. Arch Toxicol 86:1861-1871

Wang H-H, Wu M-M, Chan MWY, Pu Y-S, Chen C-J, Lee T-C (2014) Long-term low-dose exposure of human urothelial cells to sodium arsenite activates lipocalin-2 via hypomethylation. Arch Toxicol 88:1549-1559

Weiß T, Henry J, Brüning T (2010) Berufskrankheit 1301. Bewertung der beruflichen (Mit-) Verursachung von Harnblasenkrebserkrankungen unter Berücksichtigung der quantitativen Abschätzung der Einwirkung der aromatischen Amine 2-Naphthylamin, 4-Aminobiphenyl und o-Toluidin. Arbeitsmed Sozialmed Umweltmed 45:222-235 